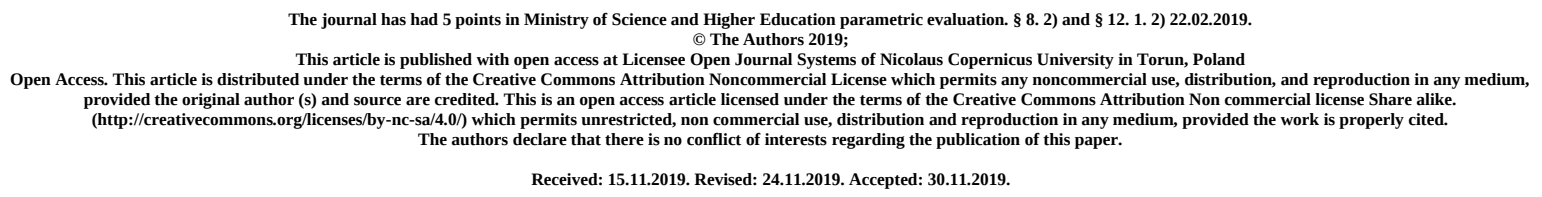

\title{
Image Olympian. Case study
}

\author{
Ilona Cięszczyk \\ University School of Physical Education in Wroclaw \\ ilona.cieszczyk@awf.wroc.pl
}

\begin{abstract}
The first part of the work presents the theoretical basis. An important aspect of this section is to present the history of the image, the various stages of its development of its precursors detailing Personal Public Relations. In this chapter we also find methods of shaping the image. Is presented step-by-step strategy of self-presentation.

The next section presents issues related to sports. It is characterized in the discipline, which starts Olympian, or pneumatic shooting.

Turning to the rest of the work, presented in the methodology of research: the structure of the questionnaire used in the questions and their purpose. These tabs are described in surveys. Also characterized the selection of the sample quantitative research. Then they developed test results and interpreted them.

The completion of this work is the chapter referring to the conclusions of the study. Indication beings and show the multifaceted image of Renata Margaret Mauer-Różańska, gold medalist in the Olympic sport target shooting air.
\end{abstract}

Key words: image, sport, sport shooting, Renata Mauer, Olympics, quantitative research

\section{Introduction}

The concept of sport science is very variously defined. In the definitions of those stresses taking care of health, improvement of physical fitness and endurance athletes concern for the well-being of the figure and hooked on the psychological aspects or the desire to compete and have 
fun. [1] As part of the sport, they are propagated higher moral values such as friendship, loyalty, honor and ethos of fair play. Today, sport is not only a higher value, but increasingly this business, consisting of professionalization and commercialization. [2]

"Sport is business, and business is business" - these words spoken by one of the managers of the largest sports club in the United States before 20- years indicate that modern sport has become a social phenomenon, a very diverse and multidimensional. Is subject to constant changes due to systematic development of civilization. Is defined as the area is not only a social activity or technological, but also economic. [3]

\section{History of Public Relations, taking into account the concept of image}

The beginnings of public relations observed in modern times is very difficult to determine because there is no clear actions and facts that pointed to it. The literature concerning public relations are marked four steps of forming and shaping the art. The authors stand out:

- Stage I which is dated to the time period from antiquity to the Middle Ages. Following think researchers like B. Rozwadowska, S. Black, T. Goban-Klas PR origins are located in India. These authors suggest that in ancient times sent spies to learn and wrote down opinions on the prevailing rulers. Another action pointing to the fact that the creation of the PR was in ancient Greece that the success of his political career was connected with the approval of the society and the policy of positive publicity, while in ancient Rome in 59 AD founded the newspaper "Acta Diurna" "Messages Day". An important event is the creation of the concepts of "Vox populi, vox Dei" - "audience", "public".

- Stage II dates back to the industrial revolution (nineteenth century). Some scholars read out the origins of PR during this period. They combine the glory days of the existence of numerous industry fortunes businessmen (eg.: John D. Rockefeller or Henry Clay Trick). While gaining wealth did not expect the public opinion which caused numerous protests and indignation. To appease conflicts with society, a new form of communication institutional advertising (advertising institutional). Then run a dialogue between the public and journalists, however, these measures have not produced the desired effects arose because apologetic articles, which were the result of bribery of journalists.

- Stage III During this period, the precursors of thought emerge public relations (Ivy Ledbetter Lee and Edward L. Barnays). First of thinkers attributed to numerous activities in the field of dialogue with the media. It was he who created the now-famous words, "The public be informed" (Let the public will be informed) and, in 1905. He called into action the world's first Public Relations agency. He preached that business owners should take measures in the field of maintaining public confidence and not mask the civil and mitigate conflicts. During this period emerge the beginnings of the Personal PR. Actions confirming this fact is employed by the Rockefeller Lee to improve his personal image. Related to the activities of the financial magnate was present in everyday situations with your family, and the first in the history of the personal visit of the mine in Colorado, where he was the owner. Further development of the image and it appears Bernyes Byoira who created the PR strategy for the newly formed State-Lithuania. Their main aim was to create a positive image of that State. Bernyes shared his skills with figures of Diaghilev's Russian Ballet stage or Bessie Smith, the business world: -Henry Ford and science Thomas Edison. He also held the post of first LP lecturer and was the author of the first textbook in the field of LP entitled "The crystallization of public opinion" Their main aim was to create a positive image of that State. 
- Stage IV- determined stage of modern times. This time is the last period of dating the emergence of the field of PR. It locates it since World War II until today. 60s as the aforementioned third period abounded in conflicts against the background of social discontent. Formed a number of feminist movements, associations of defense of minority rights and student movements. PR corresponded to increased development around the world. In Great Britain formed the Institute of Public Relations (1948), Poland will be brought to life Polish Public Relations Association headed by Alma Kadragic. The next step is the creation of the Code of Ethics, Polish Public Relations Association. Like mushrooms after the rain growing consulting agencies.

Featured above clearly indicate stages in four different moments in the history of talking about the "beginning" of public relations, and each of these steps represents a different group of business and science. An important aspect in the history of the development of the dialogue with society is also the term "image". He is the first to use this concept P. Martineu to the companies. He detailed the importance of image and those who are potential recipients of its impact. The second person who explored the term is discussed SH Britt. And he talked about how the image of the image. He identifies it with public stereotypes behind which people follow in their decisions. [4]

\section{Methodology of the image (self-presentation)}

One of the wide range of tasks facing the Personal Public Relations is to create a positive image of the individual. These activities are aimed at the use of tools and techniques self-presentation to consciously control the image of his ward. One researcher Mark Leary claimed that:

Self-presentation is the process of controlling the way in which others see the person, this "manipulation exerted impressed. [5]

And the definition of Personal Public Relations reads:

Personal PR is a purposeful, intentional, conscious, methodical and coherent system of communication activities aimed at disclosure of the specific characteristics of a person important in its public activities by building a two-way relationship with this part of the environment for which its activity is significant. [6]

Notes the correlation between the above definitions. It draws to the existence and operation of the concepts of self-presentation and personal PR. One of researchers - sociologist Erving Goffman in his publication "The Man in the theater of everyday life," recalled the life and compared them to the theater where the show is played. He wrote that the body is like an actor on the world stage, who cares and pays special attention to its image, using a variety of props, costume or set design. It is also important behavior, speech and human motives causing the behavior. Authors such as Baumeister, Tice and Hutton (1989) and Szmajke (1999) grouped the tactics self-presentation in the two groups. They singled out:

1. Defensive tactics self-presentation

2. Assertiveness-conquering tactics self-presentation

The first group is focused on activities related to defense, security or maintenance of previously earned and the created identity and reputation. The body shall take these measures to avoid defeat against self-presentation. This group includes such tactics as self-handicapping, apology or excuse. It includes also an excuse or supplication. The second group-oriented tactics tactic is to create or consolidate or acquire a new identity. The tactics of these places' emphasis on the success on the ground of self-presentation. There are: ingration, self-presentation, shining example. In the world of science, researchers occupy different positions on models, theories and 
concepts by creating the image of self-presentation. Adamus-Matuszyńska indicates that the conclusions of these studies are clearly needed to be able to determine the state of consciousness in correlation with the strategy of building the image. She emphasized the fact that each unit can control the actions related to the creation of image, too, so going to a certain extent with athletes. [7]

Many times, it so happens that a player does not control the media which communicates through his attitude, behavior. During his preparation for the training focuses all attention on the coach, players or teammates totally forgetting about the fans around him, to which this message arrives. Similarly, when bursts of joy or defeat. The situation is different during public meetings or conferences. A. Szmajke in his book "Self-presentation. Masks. Pose. The mines "distinguished self-presentation strategies such as:

1. Image of a person attractive - we are talking about raising its attractiveness in relation to the environment. The most common example of this action is tracking trends matching clothes fashion, speaking out on issues that are current on the front pages of newspapers, participating in various competitions, TV programs. These actions are not in line with the identity of the individual but also are not in conflict with it.

2. The image of people angry- strategy of self-presentation is intended to produce fear and anxiety in people that interact with the unit. Such behavior emerges an image of the fearless, courageous and confident.

3. The image of competent people - image of a person in this strategy a person uses the techniques of self-promotion. Presents in every possible way to achieve their professional background and personal. Creates as individual knowledgeable in the art to be perceived by others as an expert.

4. The image of moral people - image of a person is an image created based on activities related to the observance of the code of ethics and standards.

5. The image of helpless people - image of a person is based strategist for showing weakness and highlighting their faults. Such a unit creates himself as a person in need of help at the same time throwing off their shoulders the burden of responsibility, and thus others may arouse sympathy and sometimes resentment.

Anna Adamus-Matuszyńska - division techniques exert impressions according to Mark Leary. They are commonly used technique known as primary (Table 1). 
Table 1. Techniques exert experience.

\begin{tabular}{|l|l|}
\hline Describing himself & $\begin{array}{l}\text { Describing himself in such a way as to have the desired } \\
\text { impression on others }\end{array}$ \\
\hline Expressing attitudes & $\begin{array}{l}\text { Expressing attitudes suggesting that the body has, and no } \\
\text { other characteristics }\end{array}$ \\
\hline Public attributions & $\begin{array}{l}\text { Explaining their own behavior in accordance with a } \\
\text { certain social image }\end{array}$ \\
\hline Memory manipulation & $\begin{array}{l}\text { Real or feigned forgetting or remembering purposes } \\
\text { self-presentation }\end{array}$ \\
\hline Non-verbal behavior & $\begin{array}{l}\text { Facial expressions, gestures, assumed the position } \\
\text { and the way to get around }\end{array}$ \\
\hline Social contacts & $\begin{array}{l}\text { Public manifestations of relationships with certain people } \\
\text { cut off from other people }\end{array}$ \\
\hline Conformism and pandering & Behavior in accordance with the social \\
\hline The scenery, props and & The use of components to the environment \\
\hline lighting & purposes self-presentation \\
\hline
\end{tabular}

Source: M. Leary, 1999 as: Adamus-Matuszyńska A. (2010): Personal PR that is creating the image of an athlete, Poznan, p. 104

Properly selected public relations techniques are the basis to implement any of the above tactics of self-presentation. Building a positive image through actions based on these tactics self-presentation, to a lesser or greater extent, always effective. Recalling the study (Barrick, Shaffer, Degrassi, 2009) in the publication Wojciszke B. (2015), which relate to the effectiveness of the use of techniques during the interview illustrate that the average correlation between self-presentation and the final assessment of the unit recruiter is $r=0.34$. After analyzing this result comes out that about 34\% greater chance of a person using techniques self-presentation than the person propagating them. [8]

\section{Sports - as shooting sports discipline (history and division)}

Weapons accompanied man since the dawn of history, and it originates from the necessity of survival, defense and get food. With the eighteenth century (industrial revolution) shooting transformed the sport. First sports, dates back to about XI age and assigned brotherhoods pullet. The idea, which is observed today has its origin much later (nineteenth century) because it is associated with the development of weapons technology, and with the formation of federations and associations shooting. Year 1983 is full of events of different origins. English-speaking countries promote simulated shooting game or pigeon bred specifically for this purpose. The following years are the establishment of the club "High Hat", [9] Was set up nationwide Shooting Association (1861) and the National Rifles Association (1871). The next step is participation Target Shooting as a discipline in the modern Olympic Games (1896). Players competed in five events, among others, were: military weapons, gun and revolver, and He played in the 1897 World Championship and Rifle (individual competitions and Group-shooting rifle and pistol). In these competitions could be afraid participated only men until 1968, when Mexico also admitted 
women. In subsequent years gradually increased the number of competitors at the Olympics. In addition to the above-mentioned debuted shooting at running deer, wild boar and pigeon flying. According to John Basiaga in his article History shooting, Zurich was the place of establishment of the Federation and the International Union of Associations Rifle (1907) comprised the following eight national shooting federation. At the time, it created the initial constitution of the organization and the first shooting rules. There was also a need for developed attitudes definition shooting, shields and weapons. Association for the time I and World War II revived the disbanded it in 1947. After more than sixteen years, the International Union of Shooting Sports decided to split the struggles of men and women, in 1989, debuted discs with electronic sensors, and in 1992 the struggles players could see for the first time on TV. [10] Another important date in the history of shooting is the year 1996 when the International Shooting Union was transformed into the International Sport Shooting Federation. The decision was taken to outline the difference between target shooting within the hunting, shooting military (tactical) from the shooting. On the Polish arena dates back to the beginnings of shooting in the same period as the European arena. Precursors of the competition with the use of firearms were previously mentioned Brotherhood Fowler (joined Christian merchants and craftsmen). According to the idea Brotherhoods established Krakow Rifle Association (1833). The subsequent years were a fruitful time for the shooting as a sport. Entered into force gros initiatives: established the arms section AD in Krakow (1913) and organized Polish Championship in shooting sports (1924) It created Polish Sport Shooting Association (1933) and sent the first representatives of the Polish Olympic discipline in the shooting. Subsequent years saw a dynamic development of this discipline, both in Poland and in the world. Referring to the source: John Basiaga article talking about target shooting sport in 2008 wrote that since 2004 the composition is shooting disciplines such as:

1. Shooting Ball:

- Competition rifle: Rifle, any standard, large-caliber, the movable shield; - Competition Pistol: gun sports, any sharp, strong central standard point; 2. Pneumatic shooting

- Competition: air gun, air rifle and a movable shield;

3. Shooting shotguns

- Competition: skeet, trap, double trap, automatic trap.

Players who take part in these competitions, especially where the use rifles must be equipped with appropriate clothing shooting, whose parameters and the individual parts are specified in the rules of the ISSF, are: stiffen jacket, special shoes and shooting glove on hand holding the weapon.

\section{Research methodology.}

Test methods have been applied to achieve the aim of this article is to examine what the image of Renata Margaret Mauer-Różańska are surveys. These methods seem appropriate to examine the phenomenon of image. With a range of tools for quantitative research work in applied questionnaire. Zaczyński its publication in the 1995 survey defines as:

The survey is a method of getting information direct questions posed by selected people via a printed list of questions called the questionnaire. [11]

Another researcher (perch) defines a survey like this:

The survey is the study of mass phenomena on the basis of properly prepared questionnaire. [12]

Quantitative studies have a number of instruments which measure phenomena then describe them quantitatively. This analysis is presented in the form of different reports and 
calculations performed statistical analysis tools. An important aspect of this research is the fact that you can standardize the information collected. The most common methods used in this area are: CATI (Computer Aided Telephone Interviews), CAWI (Computer Assisted Web Interviews), PAPI (Paper and Pen Personal Interview). Researchers quality quantity and are obliged to make a choice regarding the analysis of the collected material. We are talking about a deductive scheme of thinking and inductive research. Graham Gibson says that the induction of a data output and an application arguing General by eating with individual cases, characterized by a multitude of occurrence. Exemplification of this is eg. The observation of individual units on a club match. The researcher wanting to explore the intensity of the support of fans in correlation with the results of the team in question is a single unit for a given period of time. After the end of the observation analyzes the collected data and draws conclusions. [13] Deductive explanation is the inverse of the above action. Researcher selecting this pattern of thinking explains the research individual case by finding a general theory or rule indicative of the phenomenon. An example of this action is, for example. Eighty observation of a woman who has decreased reaction time. Analyzing the various theories and research finding is that when people get older their reaction time is prolonged. The conclusion which arises is that that woman has a prolonged reaction time because it results from the body's aging process. Most quantitative research is deductive in nature. To formulate hypotheses on the basis of a general law or phenomenon, then it has a confrontation with reality.

Analyzing the above characteristics of qualitative and quantitative methods as well as the goal of the research work was chosen by both the methods outlined above. Interviewed an individual with the person whose image is examined as well as a questionnaire survey questionnaire.

\section{Results of the survey}

A survey on the image Renata Margaret Mauer-Różańska was conducted from 2 to 30 May 2016 year. In the first part of the questionnaire was Imprint, which consisted of 2 Questions - age and sex of the test respondent. Then, respondents gave answers to 14 questions (13 questions open and one closed). Respondents were also asked to answer supplementary questions 6 . The responses to the supplementary questions used Likert scale. The study involved 35 respondents aged 18-29 years, including 20 women and 15 men. They were students of the Academy of Physical Education in Wroclaw, who studied at the sport, and the second degree. These individuals were selected because of their direct contact with Mauer-Różańska within classes. The conducted study was designed to answer the question, what image has Malgorzata Renata Mauer-Różańska in academia.

The first question concerned the knowledge of the respondents' opinion about:

1. What comes Mr / Ms mind when he hears / sees Mrs. / Mr. person Renata Margaret Mauer-Różańska?

In response to your inquiry, most of the respondents (20) indicated that Renata Margaret Mauer-Różańska they associate shooting. Then the 19 people mentioned the Olympics and Olympic medals. These results demonstrate the high impact on the image of sports achievements Mauer-Różańska. Often the athlete is evaluated through the prism of sports career and performance.

There are also cases where riders are judged by actions at the end of their sporting career. Respondents who have suffered to such activities was four. Other indications related 
attitudes (respect, admiration, appreciation, authority 6). Two people indicated that nothing comes to mind when you see or hear about Olympian. Responses to this question indicate,

2. Another examined the question of what associated person Renata Malgorzata MauerRóżańska?

This question confirmed earlier answers of respondents. Figure Renata MauerRóżańska is associated most often with target shooting, as evidenced by the display 18 by the respondents. Also indicated for combination associated with successful Olympian (14 persons) such as Olympic medals and the Olympic Games. A Renata also associated with sports, in general terms, (8) as academic lecturers (6) as well as being quiet and infested (6). Two people had no opinion on this subject. These responses may indicate a lack of interest surveyed sports discipline which is shooting.

3. Another question was who is: Renata Mauer-Różańska?

Among the most frequently given answer they were given that the medal is MauerRóżańska / Olympian (18), and 13 people reported answer "athlete". confirms a good knowledge of the form, as indicated by the responses related to the exchange of its sports achievements (Olympic gold and bronze). This picture of the players may argue that respondents watched sport Olympian struggle, or is due to the nature of the university, which made learning. Two people identified Mauer-Różańska as a woman, one person did not answer this question. Such a response can be conditioned athletes' ignorance or show an interest in other sports disciplines.

\section{What Mr / Ms opinion deals with Renata Margaret Mauer-Różańska?} university

Respondents indicated that competitor currently engaged in teaching, lecturing at the

- such indications were 23. In the selected group surveyed the answer was obvious answer, because they had classes with that Olympian in Marketing and Propaedeutic Olympic sport. Mauer-Różańska holds the position of academic teacher at the Academy of Physical Education in Wroclaw and the Lower Silesian School. Respondents indicated that is also involved in activities to promote the sport, as mentioned by 7 people. Olympian very often and willingly engages in activities which aim to promote sport and encourage people to take an active lifestyle. As far as possible show up at sporting events, often covering them patronage. Other indications of practicing sport (5). Only one person He does not know what Renata is currently.

\section{What Mr / Ms specialized opinion Renata Mauer-Różańska?}

On the question of, what specialized Renata Mauer-Różańska almost all those surveyed indicated that specialized in shooting (32). This may indicate the fact of communicating about this for a former athlete. An important premise for conditioning the response obtained is also often present a Mauer-Różańska the pictures with pneumatic gun, which became her inseparable attribute. One person pointed out the activities for the promotion of sport. This response may be due to duality career Olympian. Mauer-Różańska during his sporting career in parallel promote sport by participating in sporting events. In parallel, also he held the post of university lecturers, so that she could encourage young people to train different sports. Two people had no knowledge of. 
6. Another question concerned what is Renata Margaret Mauer-Różańska relationships with students?

Respondents answering this question, pointed out that Renata relationships with students is perceived as a kind and sympathetic person of such indications was 24 . This is due to a very strong commitment Mauer-Różańska to work as a lecturer. It is always helpful and willing to take the time to talk with the students. It was also stressed other personality traits that appear in the said relationship such as understanding (8), kindness (5) open (4). It was also noted that it is thereby very culture (2) and a modest (2). It manifests itself in working with students. As a university lecturer did not demonstrate superiority because of sports achievements. We are happy to share them, and students can always count on a warm word and courage by adding Mauer-Różańska. A small group of respondents - 6 respondents had not taken to define these relationships Mauer-Różańska. Clearly, they formed a group, representing no opinion on the relationship between the former competitor shooting and students.

\section{What think Mr / Ms Renata Margaret Mauer-Różańska in relation with the media?}

The responses of respondents regarding the relationship with the media Renata MauerRóżańska, there are many attributes such as: a modest (6) and open (6) controlled, (5) emphatic mile (4) and professional (3). These responses are mapping relationship Renata Margaret MauerRóżańska with students. The respondents are the recipients of the press specialist sports. It is based on her answering. Four people surveyed believe, however, that there is little media. This is due to a small amount of newspaper articles referring to the form of Olympian. Gold medalist does not promote through social media and rarely gives television interviews. Among the respondents there were 9 people who do not know anything about these relationships with the media. This may result from the lack of participation in a narrow specialist group of athletes associated with target shooting. In the general press articles Mauer-Różańska as the main character does not appear. It also may result from elitist discipline, and thus, qualify for the niche of the sport. This sport is less spectacular than football and has a very small group of fans. That is why television stations outside the days when the Games take place does not transmit, and thus does not popularize the sport. A small group of consumers is also promoting the sport. Three indications related to other personality characteristics (concrete, authentic, confident of his).

8. Another question concerned the way in which Renata Margaret Mauer-Różańska could improve their image in the media?

One third of respondents (10) had no opinion on how the athlete could improve their image in the media. It is possible that this is due to lack of information on the image of the respondents, the methodology of shaping and strengthening its communication in the media. Eight people have taken to identify activities that enrich the image of Mauer-Różańska. Their proposal was to increase activity in the media by Olympian. Another 5 respondents indicated that should increase social activity and actions for the development of sports. These responses may indicate a lack of activity on social networks. Mauer Różańska - 2 has an account on the "Facebook" However, these angles do not show any activity. She was a contestant does not set up an account on any other social networking (Twitter, LinkedIn). According to three people Olympian does not need to enrich its image in the media because there is no such need. While two respondents 
indicated that they should change the style of dress. This sentence is determined by the effect of "first impression". Those media, "shiny on the screen" often are seen first by the style of dress and behavior. One of the respondents indicated that Mauer-Różańska should be more confident to enrich its image in the media. This person defines the image of the Olympian through the prism of her personality. "Shiny on the screen" often are seen first by the style of dress and behavior. One of the respondents indicated that Mauer-Różańska should be more confident to enrich its image in the media. This person defines the image of the Olympian through the prism of her personality. "Shiny on the screen" often are seen first by the style of dress and behavior. One of the respondents indicated that Mauer-Różańska should be more confident to enrich its image in the media. This person defines the image of the Olympian through the prism of her personality.

9. Do you / your opinion Renata Margaret Mauer-Różańska stands out from other athletes who have completed their sporting career?

In the opinion of respondents Renata Margaret Mauer-Różańska does not really stand out from other athletes who are no longer economically active. Such persons were 19. This may be due to low activity in the media, respondents pointed out that in the above questions. This may also be the source of the lack of activity on social networking sites. Mauer-Różańska promotes sports in the district of Lower Silesia, and the arena all over the country do not take any action which results in the above result. Opinion surveyed may also be conditioned Olympian comparison to other players' sports such as inactive. Polish rider and bike track - Czeslaw Lang, who is co-organizer of the Tour de Pologne (Race around the Polish). Mentioned competitor cycling races throughout the period he devoted himself professionally by winning numerous medals, and his biggest success was winning the silver medal in the cycling race with a mass start at the Moscow Olympics (1980 year). Draws a correlation here with Mauer-Różańska. Czeslaw Lang decided to transfer the experience gained on Polish territory became the early 90's Director General of Lang Team and Tour de Pologne, endeavoring to restore the splendor of the aforementioned professions cycling. His merit is the fact of becoming a Tour de Pologne one of the most important cycling event in the world, consisting of a series of the prestigious UCI World Tour. He also founded his self-presentation page where he described his work as an active professional player and describes the present life. On its website we read: Draws a correlation here with Mauer-Różańska. Czeslaw Lang decided to transfer the experience gained on Polish territory became the early 90's Director General of Lang Team and Tour de Pologne, endeavoring to restore the splendor of the aforementioned professions cycling. He created a lot of events that have become cyclical events that attract crowds of bike lovers. It even Skandia Maraton Lang Team Grand Prix MTB, Nutella Mini Tour de Pologne, the Tour de Pologne Amateurs or Tauron Lang Team Race. [14]

Comparing these figures (Mauer-Różańska, Lang) to each other, clearly draw the grounds 19 indications that the gold medalist of the Olympic Games does not stand out from other athletes inactive, while the task of the above questions affirmatively answered 16 people. The reason for such responses may be watching Mauer-Różańska through the prism of the activities carried out in Lower Silesia. We are talking about activities for the local community, the tenure councilor. He is also a member of the Athletes' Commission and the Committee on Women and Sport at the Polish Olympic Committee and the head of the Wroclaw Sports Council. It encourages and promotes numerous sports in Lower Silesia.

10. Another Margaret Mauer-Różańska stands out from other athletes who have completed their sporting career question for a complement to the previous questions and Renata clarified. 
According to people involved in the study, Renata stands out from other athletes who have completed their sporting careers that is modest (5) active in sports (4), the working (3), and appears in the media (2). Respondents also pointed to other individual characteristics that make Olympian stands out from other athletes who have completed a career sports such as lack of moral scandals, the combination of science career, winning a medal important event, high achievements, taking an active part in the provincial parliament.

11. The survey also asked respondents what behaviors Ms. Renata Margaret MauerRóżańska strengthen non-sports sports her image?

According to research group this friendliness (10) and modesty (9) strengthens the athlete non-sports sports image. The two above mentioned characteristics correlate with the continuity of behavior carried out by Olympian, on which it builds its image. Other respondents (8) pointed out in different areas of knowledge, attitude, core values, good manners, intelligence, authenticity, being a university teacher, understanding, professionalism, being a lovable person, contact with students or indicate her place of work. Among the 8 people surveyed indicated that they did not know what behaviors could strengthen its non-sports sports image.

12. What behaviors Ms. Renata Margaret Mauer-Różańska Lord / you think negatively affect its image?

The largest part of the respondents cannot identify what behaviors Olympian adversely affect its image. The source of this type of response may be the lack of high activity MauerRóżańska media, thereby tracking the actions people have no way of comparing the actions Olympian. Another reason for such responses may be a lack of interest on the part of respondent's sport discipline, which is shooting, and thus do not follow decisions players. People in the number 11 say that there is no such behavior that expected negative impact on the image of Mauer-Różańska. The reason for this may be little or no objectivity relating to the evaluation of players, or the broad promotion of the actions by these individuals. Three respondents have no job on this. Only 3 people believe that the negative impact on Image Mauer-Różańska affected by the lack of activity on social networks and in the media. Olympian has 2 accounts on the social networking site "Facebook, Inc." In these accounts, there is no activity. competitor does not have accounts on the other. Among the respondents were 3 people who have given other individual indications, such as the lack of a doctorate, style of dress, specific expression. One of the people the question is examined through the prism of academic discourse, as indicated by the answer "no doctorate."

13. Is Renata Margaret Mauer-Różańska can be an authority?

The vast majority of people (32 people) replied in the affirmative to the question posed. Other people (3) in favor of that Mauer-Różańska is not authority.

14. Why Renata Margaret Mauer-Różańska is the authority?

Indications were as follows: the busy / lot reached (16) is a model to be followed (15) is activated (9) and modest (7). 
Another group of questions addressed respondents were supplementary questions. The respondents had to locate their answers on a five-point Likert scale. In response to the scale mentioned above which was a choice of respondent are: completely agree, I agree, I have no opinion, disagree, strongly disagree.

1. The first supplementary question was: Do respondents agree outstanding athletes participated in social campaigns / image-prepared with the participation of athletes with an indication of Renata Margaret Mauer-Różańska.

On the question of 28 people with 35 completely agreed with the acceptance of outstanding athletes in social campaigns / of image. Indications for the answer "you agree" was 7. Nowadays, it is common practice to use images of athletes to encourage the public to sports or other initiatives. Numerous sponsorship contracts players even impose their activities to promote a particular brand or product. A good practice is also imposing players football players under contract (basketball) realizing tens of hours for charity to society eg.: Marcin Gortat performs these activities by organizing meetings with children as part of "Marcin Gortat Camp". Respondents who do not accept such actions were 5, including a 'do not you agree "marked 4, Two respondents have no opinion on the subject.

2. I follow the opinion athlete (Renata Margaret Mauer-Różańska) deciding to participate in the competition.

The next question asked whether respondents believe athletes are guided (MauerRóżańska) when it comes to taking part in different sports. The largest number of responses represented by 14 people is "no opinion." This may result from the small number of public appearances Olympian. Said small number of public concerns the political sphere. Another group of people in favor of taking into account the opinion of the athlete. Such indications were 9. This group can be characterized by a tendency to make decisions taking into account the experience and authority of other athletes. While 12 people, making decisions about participation in the competition is not guided by opinion athlete. An important aspect of this result response may be imposed on the number and rank of the competition by the coach or the players co-training. Units that regularly attend training sessions, while closely directing the per sport, do not analyze sporting events and calendar played competitions in all disciplines, but his coaching staff if he chooses the competition because of the discipline, raga and their benefits, leaving behind the words high-level athletes who urge to participate in specific occupations.

3. I participate in competitions over which Renata Margaret Mauer-Różańska its patronage.

Answers to the question whether an individual takes part in competitions over which Renata Margaret Mauer-Różańska its patronage correlate with the answers of respondents to the question 16. Of the 8 people surveyed indicated that they take part in competitions over which our Olympian its patronage. This result is very similar to the responses earlier in question (9 indications). The reason for this result could be a "fan club" Olympian. It is also possible that individuals take part in such competitions, which are under the patronage of former players shooting motives possible to achieve material benefits. The action taken by the organizers of the competition, which is based on the request of patronage competition by Olympic medalists, and not only aims to attract a large number of people willing to participate in such a venture. Using the image of the athlete connects with attractive prizes. 
People who do not have an opinion on this subject is 8. When analyzing the responses observed them moving. The question posed earlier showed most respondents answered, "no opinion" (14) in this question statements represent the largest number of responses disagreeing with the statement subject to verification of the respondents. Such indications were 19 at the 5 'do not you agree "and 14 to" strongly disagree. "

4. Athletes is a closed group, living in his own world. Olympian Renata Margaret MauerRóżańska is a representative of the group.

In the questionnaire survey were also asked about whether, a group of athletes is closed, living in his own world. Olympian Renata Margaret Mauer-Różańska is a representative of the group. The vast majority of respondents (21) believe that although this group of athletes closed, living in his own world, the gold medalist in shooting sports is not a representative of the group, 6 people disagreed, while 8 persons have no opinion on the subject. Such responses reflect the resolution indicated in the above question. Units indicate that Mauer-Różańska is a very nice person, always carrying help if someone needs it, we want to share their experience, which confirms that the gold medalist of the Olympic Games is not representative of a closed group of athletes. Also involved in efforts to sport and society as a counselor and chairwoman of the Sports City Council. The remaining number of responses ("no opinion" (8) "agree" (2) "Strongly agree" (4)) may indicate a perception by respondents as the openness of high activity in the media such as social networking, interviews to newspapers and TV reports. From this perspective Mauer-Różańska definitely is closed on the media, which is reflected in the lack of recovery from initiatives and to encourage contact with the person.

5. Renata Mauer-Różańska willingly shares his experience

According to Renata 25 people very willing to share their experience, 6 people have no opinion on the subject. While 4 people think that doing it reluctantly.

6. Renata Mauer-Różańska is often seen at various celebrations, not only sports.

Of the 14 respondents it is of the opinion that the athlete is often being seen at various celebrations, not only sports, as many have no opinion on the subject. While 7 people think that rarely see, Olympian at various ceremonies.

\section{Completion and conclusions}

To sum up, the aim of this study was to examine and define the image of the athlete in this case gold Olympic shooting. This study is a continuation of research based on the analysis of the image of that Olympian breaker on the daily press. [15]

The target group, which has been taken into account in these surveys are students of the Academy of Physical Education in Wroclaw, studying at the Faculty of Sports Sciences, majoring in Sports. The research group consisted of 35 respondents aged 18-29 years. The study included 20 women and 15 men. Respondents were asked to complete a questionnaire which focused on questions concerning the activity of sportswomen in the media and beyond. Also asked about her knowledge of the form, its general characteristics (whether and what stands out) and its authoritarianism. After a preliminary analysis of the collected material was 
observed significantly significant difference in point of view of perception and Renata Margaret Mauer-Różańska.

After analyzing the results of the survey showed conclusion that it is moderately positive. The first proposal as arises is that respondents can very well accommodate Mauer-Różańska figure in the social space. Knowledge of such a "world" is derived. They can indicate which represented the sport (sport shooting) and identify it with the values flowing from the sport. This shows that the messages that sends sportswoman towards society are aptly formulated which translates into a positive image. In relations with students determined to be "nice", "nice", "benevolent", "open", "understanding" and in relations with the media in addition to the range of positive attributes: "modest", "open", "controlled" or "professional" fell expressions such as: "little media". Such a statement could have a negative impact on the image. It was decided to complete the questions and issues to strengthen the image of the media. With it appeared the expectations of society towards the young Olympian.

Attention was drawn to a small social activity, low activity in the media, lack of confidence or changing style of dress. These aspects also do not have a positive impact on the image. Respondents also pointed out that the Mauer-Różańska does not stand out well against other athletes who finished his career. Olympian reinforces the sporty image respondents According to the opinion "benevolence", "modesty", "control", "openness", "governmental activities" or "social activities." And the negative impact on it "With it appeared the expectations of society towards the young Olympian. And the negative impact on it " These aspects also does not have a positive impact on the image. And the negative impact on it "the lack of a doctorate "or" dress code ". Creation of a positive image of the golden Olympian is a statement by the respondents that Mauer-Różańska is an authority, because it is "a role model", "modest", "busy" or active. Summing up the opinion of the respondents builds the image of MauerRóżańska, sportswomen representing sport shooting as an open, willingly offering assistance, forgiving and humble person. It is also involved in activities for the local community, promotes sport and shares her experience. On the other hand, blemish on the image of social activity is low (inactive accounts on social networking site Facebook INC.), Lack of confidence, attitude withdrawn.

Conclusions

The completion of this work is the chapter referring to the conclusions of the study. Indication beings and show the image of multifaceted Renata Margaret Mauer-Różańska, gold medalist in the Olympic sport target shooting air.

\section{References}

1 Tarasiewicz R. (2009), In sports logistics, Logistics 3/2009.

2 Sznajder A. (2008), Sports marketing, PWE, Warsaw.

3 A. Sznajder (2007), Characteristics of professional sport, National Economy, No. 10.

4 SH Britt, The Psychological Principles of Corporate Imagery, Business Horizons, 1971, Mix. Well. 1.

5 M. Leary. Exerting impression on others. The art of self-presentation. Gdańsk 1999 [in:] A. Adamus-Matuszyńska, Personal PR, Which created the image of an athlete, [in] P. Godlewski W. Rydzak, Trębacka J. (eds.) Public Relations in sport, Poznan 2010 p. 85.

6 A. Adamus-Matuszyńska, Personal PR, Which created the image of an athlete, [in] P.Godlewski W. Rydzak, Trębacka J. (eds.) Public Relations in sport, Poznan 2010 p. 95.

7 A. Adamus-Matuszyńska, Personal PR, Which created the image of an athlete, [in] P.Godlewski W. Rydzak, Trębacka J. (eds.) Public Relations in sport, Poznan 2010 p. 101. 
8 B. Wojciszke, Social Psychology, Warsaw 2015, p. 171.

9 Club "High Hat" - That was his idea of shooting the pigeons put on the sign of the shooter. The person releasing the birds That would let them out of a hat. In Subsequent years it turned into pigeons on a person releases dozens of bullets on the machine.

10 J. Basiaga, Shooting History [in] Bibliotheca Nostra. Bulletin. Mariusz Pacha (ed.), Katowice, 2008 No 3 (15), pp. 25-32.

11 W. Zaczyński, Research work teacher, Warsaw 1995, s. 146.

12 W. Perch, New pedagogical nightingale, Warsaw 1998, p. 22.

13 G. Gibson, Analyzing qualitative data, Warsaw 2015, p. 25.

14 http://czeslawlang.com/zyciorys/ [access: 11.27.2016].

15 Cięszczyk I. Media Image of Former Olympian. Renata Mauer-Różańska Case Study. Journal of Education, Health and Sport. 2019;9(8):153-178. eISNN 2391-8306. DOI http://dx.doi.org/10.5281/zenodo.3371647 